\title{
Nature and Extent of Corporate Social Responsibility in the Indian Banking Sector
}

\author{
Mohammad Saleh Miralam ${ }^{1} \&$ Vikram Jeet $^{1}$ \\ ${ }^{1}$ Department of Business Administration, College of Business, University of Jeddah, Jeddah, Saudi Arabia \\ Correspondence: Vikram Jeet, Department of Business Administration, College of Business, University of Jeddah, \\ Jeddah, Saudi Arabia.
}

Received: June 16, 2020

Accepted: July 26, 2020

Online Published: September 3, 2020

doi:10.5430/rwe.v11n5p48

URL: https://doi.org/10.5430/rwe.v11n5p48

\begin{abstract}
Corporate social responsibility (CSR), are societal initiatives of an organization for the community welfare and development. The purpose of the present study is to highlight the corporate social responsibility disclosure of Indian banks for the financial year 2014-15 to 2016-17. The contribution of Indian banks in CSR initiatives has been observed in the form of development of the rural sector, the contribution in basic education, generating more employment opportunities, public healthcare, and sanitation, etc. CSR has been emerged as an important factor in facilitating sustainable growth and valuing the stakeholder and featured as a competitive edge in the banking sector over its rivals and improves the reputation. The results of the study highlighted the compounded CSR spent and sector-wise CSR contributions by the Indian banks during the period of study. A compounded downfall of 7.70 percent has been observed in the growth of the amount required to CSR spent. Simultaneously, the downfall of 8.39 percent in the actual CSR spent has also been recorded in the study. But on the other hand, the amount of CSR spent of all sample banks has been increased by a compound growth of 22.60 percent during the period of study. Besides, the growth analysis of "sector-wise" CSR spent reflected an increase in the compound growth of all sectors by 21.80 percent.
\end{abstract}

Keywords: Indian banking sector, corporate social responsibility, CSR spending, and community development

\section{Introduction}

In the attainment of organizations' primary objective of earning profits and sustainability, ever going firms' commercial activities are continuously affecting the social and environmental resources. In this scenario, organizations' efforts in creating a balance in economic, social, and environmental imperatives, the concept of corporate social responsibility (CSR) has emerged as an important concern (Schwartz \& Carroll, 2003; Maon, 2009). Thus, CSR can be defined as activities of an organization that performs over and above the constitutional requirement for the benefits of society (Garriga \& Melé 2004). It emphasizes the moral duty of any organization towards the society and environment. Bowen (1953) defined CSR as "the obligations of businessmen to pursue those policies, to make those decisions, or to follow those lines of action which are desirable in terms of the objectives and values of our society". Drucker (1954) extends the definition as "it has to consider whether the action is likely to promote the public good, to advance the basic beliefs of our society, to contribute to its stability, strength, and harmony". Carroll (1979) defined CSR as, "The social responsibility of the business encompasses economic, legal, ethical, and discretionary expectations that society has organizations at a given point in time".

Friedman (1970) elaborated CSR in an entirely different way, "companies should only be obligated to maximize their profit within the boundaries of the law and minimal ethical constraints". Many researchers conceptualized CSR as a panacea, which creates a bridge to connect the global social and environmental challenges with the mainstream of society. No doubt, CSR is the moral obligation, but organizations are also facing societal pressure concerning social and environmental issues. Given that organization are responding to such pressure and emphasizing on the conception of CSR (Bénabou \& Tirole, 2009). However, researchers have discussed the different motives of organization for CSR involvements such as pressure of activist groups (Hond \& Bakker, 2007); persisting economic conditions and corporate behavior (Campbell, 2007); charitable intensity (Brammer \& Millington, 2008); intrinsic drivers and extrinsic (trade-related) drivers (Muller \& Kolk, 2010); corporate visibility (Li, Morris, \& Young. 2019); consumers' CSR perception (Sen \& Bhattacharya, 2001); corporate environmental ratings (Chatterji \& Toffel, 2010), etc., Dhingra and Mittal (2014) conceptualized and acknowledged great importance and recognition of CSR as the concern for environmental sustainability, social development, and management of natural resources. Zain (1999) underlined the 
CSR role in creating and sustaining the organization's relationship with its members and stakeholders. It has been emphasized that CSR initiatives and standards should be part of the organization's regulations and must involve in the social and environmental issues voluntarily. In which the expenses incurred on the CSR, protects the societal image of the organization and creating a competitive advantage over the competitors, (Raju, 2014).

\subsection{CSR in India - Provision Under the Companies Act, 2013}

Presently, Indian organizations are taking a proactive approach towards CSR initiatives, in which the role of institutional component and active participation of government encouragement played a crucial role. The emerging trends of CSR have been observed in the form of environmental, social, and governance development initiatives, throughout every industrial sector in India. CSR has been considered as the 'trustee of the resources' representing the integral component in Indian organization culture (Narayan 1966). Numerous researchers and agencies have been acknowledged the contribution of Indian companies for the benefit of society. Gupta (2007) highlighted the contribution of Indian organizations towards social development which is beyond their normal business affairs. It has been stated that CSR approaches in India are the philosophical and ethical dimension, which is indispensable for organizational sustainability (Aspal \& Singh 2020). Since the Indian government induced the notification of Section 135 of Companies Act, 2013, imposed CSR as the mandatory affairs for organizations, under the compliance of certain criteria of the section. As per the stated provision, organizations under three conditions must adhere to the provision of CSR Act viz. a viz. (i) "The net worth of Rs. 5000 Million or more", or (ii) "Sale proceeds of Rs. 10000 Million", or (iii) "A net profit of Rs. 50 Million during a year". It is a legal obligation to frame a CSR committee if any company fulfilling any above-stated conditions. Further, the provision also imposed responsibility on the directors of the committee to ensure that the minimum expenditure on the CSR initiative during a year, which is fixed at a minimum of 2 percent of the average profit of three previous years. A positive impression of the Indian corporation can be observed, as increased interest in supporting of non-profit agencies, construction of basic infrastructure in form of schools and hospitals, and active donations in the natural calamities and pandemic situations. On the individual front employees' volunteer efforts against the evils of society such as drug abuse, sanitization of slum areas, cleaning the beaches, and tree plantations can be observed throughout the country.

\section{CSR and Banking Sector: Review of Literature}

Concepts of corporate social responsibility and business ethics are becoming extremely topical as the integration of moral principles significantly highlighted in all commercial units. Now, in the banking sector corporate social responsibility and ethics are perceived as an appropriate marketing tool to make their presence in society. Numerous and extensive literature signifies the contribution of banking sectors towards CSR around the world. Like, Kvasničková, Margarisova, and Št'astná, (2012) conducted five years of a comprehensive study of the fund allocated by the banks, specifically for philanthropic purposes. In this period of five years, all banks contributed to philanthropic purposes even in the financial crises, and the results have shown a significant positive impact on the revenue of the banks. Soana (2011) studied the financial and social performance of the Italian banks. The results of the study have shown that there is a negative correlation between social and financial performance. Hence, an investment in CSR had not encouraged the impact on the economic advantages for the banks. Supporting the above study, Gibbons (2011) also found no transparency for CSR in many United Kingdom banks. Chedrawi, Osta, and Osta, (2020) consider CSR as an important issue in the world's banking industry, where a need of taking care of the stakeholders' interest, social and natural environment, with the increase in the legitimacy, become more crucial.

Burianová and Paulík (2014) revealed that Czech commercial banks found lacking the transparency of the information related to the CSR. Hence, the CSR index of selected banks reflected the average performance of the bank. Nájera (2020) presented a statistical description of the evolution of sustainable banking research programs on their competitiveness. Tran and Nguyen (2020) investigate the relevance of CSR in the paint industry. The study analyzed the CSR relationship on the B2B model, specifically analyzed the impact on the business customer and customer loyalty, satisfaction, and commitment. The results of the study have shown a significant increase in customer satisfaction and firm reputations through the strategical implementation of CSR activities. Bianchi, Bruno, and Sarabia-Sanchez (2019) emphasized the encouraging impact of CSR on customer purchase behavior and the firm's reputations, considering the impact of brand image and loyalty.

Dhingra and Mittal (2014) studied the CSR reports of Indian banking institutions and found that only a few banks have shown regularity in CSR disclosure as per the recommended guidelines. There was no uniformity in the standard rating of CSR in comparison to the financial rating. A casual approach toward the socio-environmental issues of few banks was also reported in the study. It was evident from the study of the most banks that CSR activities are mainly concerned to give donations to the charitable trust and NGOs. The casual approach towards CSR was observed where the institution's initiatives were of ad-hoc nature, which was not connected with the business processes and not able to provide present records of expenditures. Murawsk (2018) examined the growing importance of CSR in the banking 
sector in the United States of America (USA). The growing participation of the banking sector in the environment and social concern has been observed in the study. A positive trend was noticed, which was reflected in the ESG reports and from the responses of various social and environmental activities' effectiveness. This situation confirms that a sound management approach allows CSR activities at every stage of the company's operations. Gangi, Mustilli, Varrone, and Daniele (2018) highlight the ongoing impact of CSR disclosure on financial performance in the European banking industry. The study confirmed positives trends in the profitability of banks through active CRS engagement practices. In the continuation, Belasri, Gomes, and Pijourlet (2020) also highlighted the positive trends in the efficiency of banks while incorporating the CSR initiatives in developed countries.

\section{Need and Objective of the Study}

It is believed that CSR has great importance in all the commercial sector. In the present scenario, it has been observed that the financial sector is fostering the investment and lending practices in environmental and social responsiveness projects. Regardless of country, culture, and banking products; banks are required to be responsible for their customers in an ethical manner. Being a socially responsible financial organization, the bank should exercise legitimate and prudent banking practices for caring for customer confidence. In the available literature, there are only a few studies and documents, exploring the CSR initiatives of the Indian banking sector has been found. However, on the advice of the Reserve Bank of India, some Indian banks have initiated to spend their profits on CSR activities. Based on the above review of literature discussed, it has been observed that the contribution to CSR by the Indian banks is very less. CSR is a novel trend and always changes in the present dynamic business environment, so this research has attempted to provide evidence regarding banking sector CSR disclosure. In this context, the present paper attempts to highlight the nature and extent of corporate social responsibility in the Indian banking sector. The study will facilitate the banks to adopt more CSR initiatives and improve their spending on CSR practices for the well-being of society.

\section{Research Methodology}

A descriptive and analytical approach has been applied in the research process. The amount of CSR spent by the Indian banks for the three years, from 2014-15 to 2016-17 has been collected from the secondary sources for the analysis. All the Secondary data has been collected from authenticated online websites and portal. For the present study, 21 Indian banks have been taken as a sample. The banks who have incurred a loss during the period of study have been excluded from the sample. Moreover, the banks that have not provided data regarding their CSR expenditure have also been excluded from the sample and, only 15 banks have remained as a part of the sample. The review has been after the study of relevant research studies of different journals and articles. An analytical, descriptive, and comparative methodology has been adopted for the study. The descriptive statistics in the form of simple statistical tools like percentage, average, and a growth rate has been applied in the study.

\section{Analysis and Discussion}

The development intensity of a country's economy significantly affects the CSR practices of the banking sector. In which social and economic developments are recognized as the strong mainstays in the sustainable economic growth of an economy. Thus, the present study is focused on highlighting the contribution of Indian banks in the social and economic development CSR initiatives in the country. Analysis of the results will also provide an insight for policymakers to diversify the contribution in different social sectors. The results of the study have been analyzed in the following table and stated in discussions.

\subsection{CSR Spent on Companies Listed on the National Stock Exchange}

The tabulated CSR spent made by companies listed on the National Stock Exchange for the years 2014-15, 2015-16, and 2016-17, is been presented in Table 1.

Table 1. CSR spent on companies listed on the National Stock Exchange

\begin{tabular}{ccccc}
\hline & $\begin{array}{c}\text { FY 2014-15 } \\
\text { (Crores) }\end{array}$ & $\begin{array}{c}\text { FY 2015-16 } \\
\text { (Crores) }\end{array}$ & $\begin{array}{c}\text { FY 2016-17 } \\
\text { (Crore) }\end{array}$ & $\begin{array}{c}\text { Compound Growth } \\
\text { (in percentage) }\end{array}$ \\
\hline Average Net Profit & 535353 & 480069 & 451744 & -8.14 \\
Amount Required to be spent on CSR & 10686 & 9688 & 9103 & -7.70 \\
Actual CSR Amount spent & 10030 & 9060 & 8418 & -8.39 \\
CSR spend as a \% of Net Profit & 1.87 & 1.89 & 1.86 & -0.27 \\
\hline
\end{tabular}

Source: nseinfobase.com 
The bird's eye view of the table reflects that the total amount of average net profit of companies listed on NSE during the year 2014-15 is 535353 (crores), which has decreased to 480069 (crores) in the year 2015-16, which signifies that there is a decrease of 10.32 percent in the year 2015-16. The total amount of average net profit of companies has further decreased to 451744 (crores) in the year 2016-17, which signifies that there is a decrease of 5.90 percent in the year 2016-17. Hence, a decrease (-8.14 percent) in the net profit in the subsequent years has been observed from the above analysis.

As far as, the amount required to be spent on CSR activities is concerned, it has been observed that during the year 2014-15 such amount is 10686 (crores), which has decreased to 9688 (crores) in the year 2015-16. It signifies that there is a decrease of 998 crores required for CSR to be spent in the year 2015-16, i.e., 9.33 percent decrease in the amount required for CSR spent over the year. But, during the year 2016-17, the amount of such has been further decreased to 9103 (crores), which indicates that there is a decrease of 585 (crores) in the amount required for CSR spent during the year. It has been found that there is a 6.03 percent fall in such amount in the year 2016-17 as compared to 2015-16. Regarding the actual CSR amount spent is concerned, it has been observed that during the year 2014-15, CSR spent is (10 030) crores, which has considerably decreased to 9060 (crores) in the year 2015-16. It reveals that there is a decrease of 970 (crores) spent in the year 2015-16, i.e., 967 percent decrease in CSR spent over the year. But, during the year 2016-17, the amount of CSR spent has further decreased to 8418 (crores), which indicates that there is a decrease of 642 (crores) CSR spent during the year. It has been found that there is a 7.08 percent fall in CSR spent in the year 2016-17 as compared to 2015-16. As far as, the percentage of net profit spent on CSR activities is concerned, it has been depicted from the table that during the year 2014-15, 1.87 percent of net profit has spent on CSR activities as compared to 1.89 percent in the year 2015-15. It signifies that the CSR spent has increased by 0.02 units. Similarly, it has been found that in the year 2016-17, the percentage of CSR spent has been decreased to 1.86 (0.03 units).

The summarized view of the Table reflects that the amount of average net profits, as well as the amount required to be spent on CSR, has been decreased during the period of study. Moreover, the actual CSR amount spent is less than the amount required to be spent on CSR during the period of study. Furthermore, the percentage of CSR spent is less as compared to the standard CSR spent percentage i.e. 2 percent. The overall compound growth of both total average net profit and amount required to be spent on CSR has been declined by 8.14 and 7.70 percent, respectively. Similarly, the decline in actual CSR amount spent, by 8.39 percent, and decline of 0.27 percent in the percentage of CSR spent, has also been observed during the study.

\subsection{CSR Spent in Indian Banking Sector}

In the Indian business undertaking, the stakeholders have not been adequately conscious about CSR disclosures. Thus, there is a great need for all business entities along with the financial institutions to disclose sustainable developmental efforts for the society and environment. The amount of CSR spent made by different banks for the years 2014-15, 2015-16, and 2016-17, is been presented in Table 2.

Table 2. CSR Spent by Indian Banking Sector during 2014-15, 2015-16 and 2016-17

\begin{tabular}{lcccc}
\hline Banks & $\begin{array}{c}\text { FY 2014-15 } \\
(\mathbf{C r})\end{array}$ & $\begin{array}{c}\text { FY 2015-16 } \\
(\mathbf{C r})\end{array}$ & $\begin{array}{c}\text { FY 2016-17 } \\
(\mathbf{C r})\end{array}$ & $\begin{array}{c}\text { Compound Growth } \\
\text { (in percentage) }\end{array}$ \\
\hline Lakshmi Vilas Bank Ltd. & 0.87 & 1.40 & 0.62 & -15.58 \\
City Union Bank & 8.05 & 8.16 & 10.68 & 15.18 \\
Karnataka Bank Ltd. & 4.89 & 6.17 & 6.96 & 19.30 \\
Karur Vysya Bank & 1.14 & 2.07 & 1.60 & 18.47 \\
South Indian Bank Ltd. & 2.30 & 4.03 & 7.28 & 77.91 \\
IDBI Bank Ltd. & 9.44 & 4.37 & 1.36 & -62.04 \\
Jammu \& Kashmir Bank & 13.74 & 28.48 & 21.86 & 26.13 \\
Yes Bank & 29.52 & 41.66 & 45.21 & 23.75 \\
IndusInd Bank & 27.32 & 33.81 & 20.47 & -13.44 \\
Kotak Mahindra Bank & 11.97 & 17.33 & 26.40 & 48.51 \\
Axis Bank & 137.41 & 135.39 & 133.77 & -1.33 \\
ICICI Bank Ltd & 172.00 & 182.00 & 170.30 & -0.50 \\
HDFC Bank & 127.28 & 305.42 & 374.55 & 71.54 \\
Grand Total & 545.93 & 770.29 & 821.06 & 22.60 \\
\hline
\end{tabular}

Source: nseinfobase.com 
The discerning view of Table 2 reflects that the total amount of CSR spent by sample banks during the year 2014-15 is 545.93 crores, with a significant increase to 770.29 crores in the year 2015-16. There is an increase of 224.36 crores in CSR spending during the year, which signifies that there is an increase of 41.09 percent in CSR expenditure in the year 2015-16. Furthermore, it has been observed that during the year 2016-17 the total CSR spent all sample banks are 821.06 crores. Subsequent enhancement in the CSR spent of 50.77 crores has also been observed during the year 2016-17. The total CSR amount spent during the year 2016-17 is 821.06 crores signifies an increase of 6.60 percent CSR spent during the year.

The table further reveals that during the year 2014-15, the ICICI Bank Ltd has the highest CSR spent of 17200 crores, followed by Axis Bank with a CSR spent of 137.41 crores and HDFC Bank with a CSR spent of 127.28 crores. Whereas Lakshmi Vilas Bank Ltd. is on the bottom-most position with 0.87 crores CSR spent during the year 2014-15, followed by Karur Vysya Bank with CSR spent of 1.14 crore and South Indian Bank Ltd. with CSR spent of 2.30 crore. The HDFC Bank has contributed the highest CSR spent of 305.42 crores in the year 20115-16, with an increase of 178.14 crores as compared to the year 2014-15. Whereas the ICICI Bank Ltd contributed second highest CSR spent of 182.00 crores, and the Axis Bank contributed the third highest CSR spent of 135.39 crores, in the sample banks. The HDFC Bank has again contributed the highest amount of CSR spent of 374.557 crores in the year 2016-17. The ICICI Bank Ltd and the Axis Bank have achieved the second and third rank among all the sample banks with CSR spent 170 30 crores and 133.77 crores, respectively. On the contrary Lakshmi Vilas Bank Ltd has the least contribution on CSR spent of 0.62 crores in 2016-17. Whereas IDBI Bank Ltd. and the Karur Vysya Bank are on the bottom-most second and third positions regarding CSR spent of 1.36 and 1.60 crores, respectively.

The summarized view of Table reflects that HDFC Bank has remained at the top position with CSR spent during the years 2015-16 and 2016-17. On the other side, Lakshmi Vilas Bank Ltd. has remained on the bottom-most position with CSR spent during the year 2014-15 to 2016-17. The growth analysis reflects that there is an increase in the compound growth of all banks by 22.60 percent. The South Indian Bank Ltd has achieved the highest compound growth rate of 77.91 percent among all the sample banks, followed by HDFC Bank with a growth rate of 71.54 percent. On the contrary, IDBI Bank Ltd. has attained the highest negative growth of 62.04 percent.

\subsection{Sector-Wise CSR Spent on Indian Banks}

The organization can choose any of the social and environmental sectors for the CSR initiatives, as there are no such conditions applied for organizations. Thus, it is important to have a concise view of organizations' contributions in a different sector. The analysis will provide an insight for the decision-makers while selecting the sectors for the CSR initiatives. The sector-wise amount of CSR spent by the sample banks for the years 2014-15, 2015-16, and 2016-17 is been presented in Table 3 .

Table 3. The amount of CSR spent sector wise for the years 2014-15, 2015-16 and 2016-17

\begin{tabular}{|c|c|c|c|c|}
\hline Sectors & $\begin{array}{c}\text { FY } \\
2014-15 \\
(\mathrm{Cr})\end{array}$ & $\begin{array}{c}\text { FY } \\
2015-16 \\
(\mathrm{Cr})\end{array}$ & $\begin{array}{c}\text { FY } \\
2016-17 \\
(\mathrm{Cr})\end{array}$ & $\begin{array}{c}\text { Compound } \\
\text { Growth } \\
\text { (in percentage) }\end{array}$ \\
\hline Eradication Hunger, Poverty, Malnutrition. & 0 & 0.33 & 2.73 & $\begin{array}{l}------ \\
\end{array}$ \\
\hline Preventive Healthcare, Water, and Sanitation. & 124.62 & 31.29 & 35.94 & -46.3 \\
\hline $\begin{array}{l}\text { Education, Employability, and Livelihoods } \\
\text { Enhancement. }\end{array}$ & 127.01 & 131.73 & 188 & 21.66 \\
\hline $\begin{array}{c}\text { Gender, Equality, and Women. Empowerment, } \\
\text { Senior Citizens Care }\end{array}$ & 15.51 & 1.14 & 12.78 & -9.23 \\
\hline Environmental Sustainability. & 56.07 & 37.73 & 17.28 & -44.49 \\
\hline $\begin{array}{l}\text { Heritage conservation, Promoting Art, Craft, } \\
\text { Culture, Public Libraries }\end{array}$ & 2.02 & 2.05 & 1.81 & -5.34 \\
\hline Armed Forces Veteran Welfare & 0.16 & 0 & 5 & 459.02 \\
\hline $\begin{array}{c}\text { Promoting national and rural sports, Paralympic, } \\
\text { Olympic sports }\end{array}$ & 1.8 & 1.96 & 4.2 & 52.75 \\
\hline Technology incubation (Central Government) & 0 & 0 & 3.42 & -------- \\
\hline
\end{tabular}




\begin{tabular}{ccccc} 
Rural Development & 122.64 & 258.8 & 465.31 & 94.78 \\
Contribution to Central Government Fund & 6.01 & 0 & 0.39 & -74.53 \\
Slum Area Development, Housing for poor & 3.92 & 0.74 & 17.96 & 114.05 \\
Others & 73.58 & 84.4 & 36.39 & -29.67 \\
Total Amount & 533.34 & 550.17 & 791.21 & 21.8 \\
\hline
\end{tabular}

Source: nseinfobase.com

As far as sector-wise CSR spent is concerned, the discerning view of Table 3 reflects that during the total amount of CSR spent in all sectors during the year 2014-15 is 533.34 crore, which has been slightly enhanced to 550.17 crores in the year 2015-16. There is an increase of 16.83 crores in CSR spending during the year, which signifies that there is a marginal increase of 3.15 percent in CSR expenditure. Further, it has been observed that during the year 2016-17 the total CSR spent of all sectors was 791.21 crore. It has been found that there is a significant increase in the CSR spent during the year 2016-17 by 241.04 crore as compared to the year 2015-16, which signifies an increase of 43.81 percent in CSR spent.

Table 3 further reveals that, during the year 2014-15, the highest CSR spent of 127.01 crores has been made on " the Education, Employability and Livelihoods Enhancement" sector, followed by "Preventive Healthcare, Water and Sanitation" Sector with the total CSR spent of 124.62 crores. Whereas, in the case, "Eradication, Hunger, Poverty, Malnutrition" and Technology incubation" sectors no amount has been spent during the year 2014-15. During the year 2015-16, the highest CSR spent of 258.80 crores has been made in the "Rural Development" sector, followed by "Education, Employability and Livelihoods Enhancement" Sector with a total CSR spent of 131.73 crores. Whereas, in the case of, "Armed Forces Veteran Welfare", "Technology incubation" and "Contribution to Central Government Fund" sectors no amount has been spent during the year 2015-16. In the year 2016-17, the highest amount of CSR spent of 465.31 crores has been made on the "Rural Development" sector, which has remained in ton the top position for two consecutive years. Whereas, in the case of the "Education, Employability and Livelihoods Enhancement" sector the second-highest spent of 188.00 has been made. On the contrary, the least CSR spent of 0.39 crores has been made on "Contribution to Central Government Fund".

The summarized view of the Table reflects that the CSR spent on the "Rural Development" sector has remained at the top position regarding CSR spent during the years 2015-16 and 2016-17. On the other side, CSR spent on "Technology incubation" has remained on the bottom-most position regarding CSR spent during the year 2014-15 to 2016-17. The growth analysis reflects that there is an increase in compound growth in all sectors by 21.80 percent. The highest compound growth rate of 459.02 has been achieved in the case of the "Armed Forces Veteran Welfare" sector. On the contrary, in the case of "Contribution to Central Government Fund" sector has attained the highest negative growth of 74.53 percent regarding CSR spent.

\section{Conclusion}

The banking sector in India has introduced embedded sustainability into the system, but the CSR efforts are far from the required. The present paper analyzes the pattern of the nature and extent of corporate social responsibility of the Indian banking sector. Based on the data available on the CSR contribution, analysis was carried out on the CSR spent and the sector-wise CSR contributions of Indian banks. The results of the present study highlight that the concept of CSR, in general, is an emerging and strategical issue with topmost corporate attention in India. The growth analysis of banks highlights that there is a fall in the compound growth of the amount required to be spent on CSR by 7.70 percent. Whereas, in the case of the actual CSR amount spent, the compound growth has been decreased to 8.39 percent. Moreover, the actual percentage of CSR spent on banks is less as compared to the standard of 2 percent during the entire period of study. On an overall basis, a significant increase has been observed in the amount of CSR spent on sample banks. The compound growth of CSR expended on sample Indian banks has been increased by 22.60 per cent. The South Indian Bank Ltd has achieved the highest compound growth rate of 77.91 percent, followed by HDFC Bank with a growth rate of 71.54 percent during the period of study. On the contrary, IDBI Bank Ltd. has attained the highest negative growth of 62.04 percent. In addition to this, the growth analysis of "sector-wise" CSR spent reflects that there is an increase in the compound growth in all sectors by 21.80 percent. The highest compound growth rate of 459.02 has been achieved in the case of the "Armed Forces Veteran Welfare" sector. On the contrary, in the case of "Contribution to Central Government Fund" sector has attained the highest negative growth of 74.53 percent regarding sector-wise CSR spent. The findings of the study contribute valuable contributions to researchers and policymakers in the field of 
CSR. The report highlights the CSR contribution of the Indian banking sector in the development of the community, further can be a basis for analyzing CSR impact on the brand identity, performance, profitability, etc.,

\section{References}

Aspal, P. K., \& Singh, M. (2020). Nature and Extent of Corporate Social Responsibility Disclosure in India: A Study of Selected BSE Companies. Asia-Pacific Journal of Management Research and Innovation, 16(1), 60-71. https://doi.org/10.1177/2319510X19898631

Belasri, S., Gomes, M., \& Pijourlet, G. (2020). Corporate social responsibility and bank efficiency. Journal of Multinational Financial Management, 100612. https://doi.org/10.1016/j.mulfin.2020.100612

Bianchi, E., Bruno, J. M., \& Sarabia-Sanchez, F. J. (2019). The impact of perceived CSR on corporate reputation and purchase intention. European Journal of Management and Business Economics. https://doi.org/10.1108/EJMBE-12-2017-0068

Bowen, H. (1953). Social Responsibilities of the Businessman. Harper, New York.

Brammer, S., \& Millington, A. (2008). Does it pay to be different? An analysis of the relationship between corporate social and financial performance. Strategic Management Journal, 29, 1325-1343. https://doi.org/10.1002/smj.714

Burianová, L., \& Paulík, J. (2014). Corporate Social Responsibility in Commercial Banking-A Case Study from the Czech Republic. Journal of Competitiveness, 6(9), 853-862. https://doi.org/10.7441/joc.2014.01.04

Campbell, J. L. (2007). Why would corporations behave in socially responsible ways? An institutional theory of corporate social responsibility. Academy of Management Review, 32, 946-967. https://doi.org/10.5465/amr.2007.25275684

Carroll, A. B. (1999). Corporate social responsibility: Evolution of a definitional construct. Business \& Society, 38(3), 268-295. https://doi.org/10.1177/000765039903800303

Chatterji, A. K., \& Toffel, M. W. (2010). How firms respond to being rated. Strategic Management Journal, 31(9), 917-945. https://doi.org/10.1002/smj.840

Chedrawi, C., Osta, A., \& Osta, S. (2020). CSR in the Lebanese banking sector: a neo-institutional approach to stakeholders' legitimacy. Journal of Asia Business Studies. https://doi.org/10.1108/JABS-03-2018-0093

Dhingra, D., \& Mittal. R. (2014). CSR Practices in Indian Banking Sector. Global Journal of Finance and Management, 6(9), 853-862. Retrieved from https://www.ripublication.com/gjfm-spl/gjfmv6n9_08.pdf

Drucker, P. F. (1954). The Practice of Management. Collins, New York USA.

Friedman, M. (1970). The Social Responsibility of Business Is to Increase Its Profit. The New York Times Magazine, Sep 13, 173-178. https://link.springer.com/chapter/10.1007/978-3-540-70818-6_14

Gangi, F., Mustilli, M., Varrone, N., \& Daniele, L. M. (2018). Corporate Social Responsibility and Banks' Financial Performance. International Business Research, 11(10), 42-5. https://doi.org/10.5539/ibr.v11n10p42

Garriga, E., \& Melé, D. (2004). Corporate social responsibility theories: Mapping the territory. Journal of Business Ethics, 53(1-2), 51-71. https://doi.org/10.1023/B:BUSI.0000039399.90587.34

Gibbons, D. (2011). Held to account: a review of Corporate Social Responsibility in retail banking from the consumer perspective. London: Centre for Responsible Credit. Retrieved from http://citeseerx.ist.psu.edu/viewdoc/download?doi=10.1.1.459.9252\&rep=rep1\&type=pdf

Gupta, A. (2007). Social responsibility in India towards global compact approach. International Journal of Social Economics, 34(9), 637-663. https://doi.org/10.1108/03068290710778642

Hond, D. F., \& Bakker, F. G. A. (2007). Ideologically motivated activism: How activist groups influence corporate social change activities. Academy of Management Review, 32, 901-924. https://doi.org/10.5465/amr.2007.25275682

Kvasničková, S., L., Margarisova, K., \& Št’astná, K. (2013). Corporate social responsibility in banking sector. Acta Universitatis Agriculturae et Silviculturae Mendelianae Brunensis, 60(2), 157-164. https://doi.org/10.11118/actaun201260020157

Li, F., Morris, T., \& Young, B. (2019). The Effect of Corporate Visibility on Corporate Social Responsibility. Sustainability, 11(13), 3698. https://doi.org/10.3390/su11133698 
Maon, F., Lindgreen, A., \& Swaen, V. (2009). Designing and implementing corporate social responsibility: An integrative framework grounded in theory and practice. Journal of Business Ethics, 87(1), 71-89. https://doi.org/10.1007/s10551-008-9804-2

Muller, A., \& Kolk, A. (2010). Extrinsic and intrinsic drivers of corporate social performance: Evidence from foreign and domestic firms in Mexico. Journal of Management Studies, 47, 1-26. https://doi.org/10.1111/j.1467-6486.2009.00855.x

Murawski, T. (2018). CSR in American banking sector. Copernican Journal of Finance \& Accounting, 7(1), 35-50. http://dx.doi.org/10.12775/CJFA.2018.003

Nájera-Sánchez, J. J. (2020). A Systematic Review of Sustainable Banking through a Co-Word Analysis. Sustainability, 12(1), 278. https://doi.org/10.3390/su12010278

Narayan, J. P. (1966). Social responsibility of business. Bombay, India: Manaktalas.

Raju, S. S. (2014). Measuring Performance of Corporate Social Initiatives: Some Methodological Issues. Implementing Corporate Social Responsibility (pp. 1-18). Springer, New Delhi. Retrieved from https://link.springer.com/chapter/10.1007/978-81-322-1653-7_1

Roland, B., \& Jean, T. (2009). Individual and Corporate Social Responsibility, Economica, 77, 1-19. https://doi.org/10.1111/j.1468-0335.2009.00843.x

Schwartz, M., \& Carroll, A. (2003). Corporate Social Responsibility: A Three-Domain Approach. Business Ethics, Quarterly, (13). https://doi.org/10.5840/beq200313435

Sen, S., \& Bhattacharya, C. B. (2001). Does doing good always lead to doing better? Consumer reactions to corporate social responsibility. Journal of Marketing Research, 38, 225-243. https://doi.org/10.1509/jmkr.38.2.225.18838

Soana, M. G. (2011). The Relationship Between Corporate Social Performance and Corporate Financial Performance in the Banking Sector. Journal of Business Ethics, 104(1), 133-148. https://doi.org/10.1007/s10551-011-0894-x

Tran, K. T., \& Nguyen, P. V. (2020). Corporate Social Responsibility: Findings from the Vietnamese Paint Industry. Sustainability, 12(3), 1044. https://doi.org/10.3390/su12031044

Zain, M. M. (1999). Corporate social reporting in Malaysia: The Current State of the art and Future Prospects (Doctoral dissertation, University of Sheffield). Retrieved from http://etheses.whiterose.ac.uk/id/eprint/3073

\section{Copyrights}

Copyright for this article is retained by the author(s), with first publication rights granted to the journal.

This is an open-access article distributed under the terms and conditions of the Creative Commons Attribution license (http://creativecommons.org/licenses/by/4.0/). 